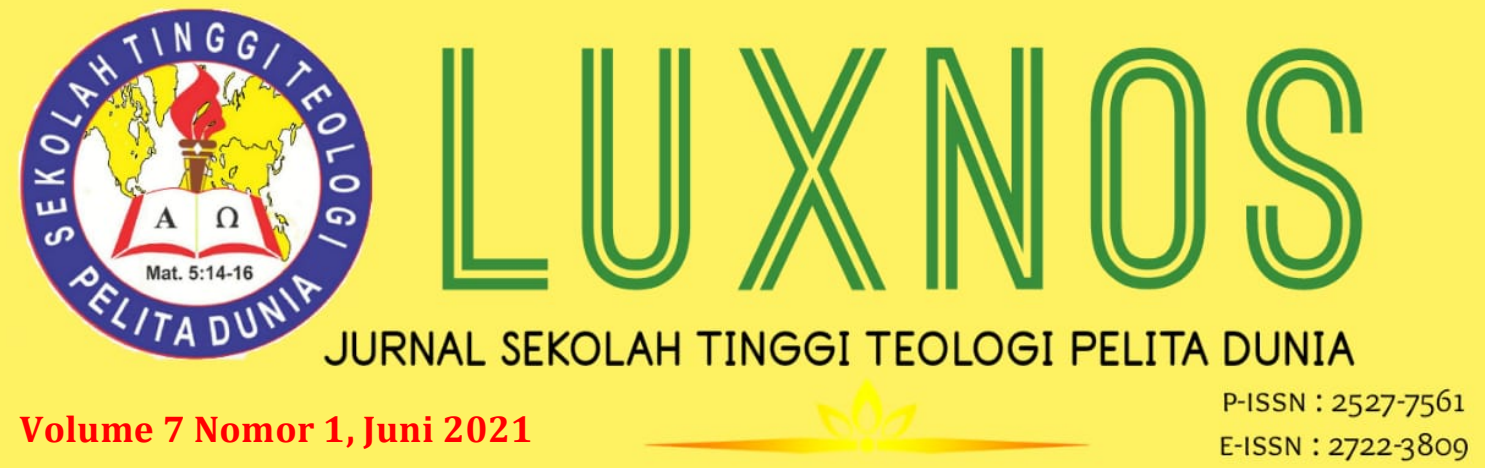

\title{
Peran Jemaat Bagi Pertumbuhan Gereja Kalimantan Evangelis (GKE) Maranatha Topan
}

\author{
Osias Kause \\ GKE Efata Pasir Panjang, Kalimantan Tengah \\ osias.kause@yahoo.com
}

\begin{abstract}
This article examines the problems experienced at the Church of GKE Maranata Topan, which is stagnating. For this reason, the author needs to look for factors that hinder the growth of the Maranatha Topan GKE Church. The research method used by the author is the exploratory method, interviews with several sources whose information is reliable and accountable at the same time using qualitative methods. The author has also served as the Head of the Resort at GKE Resort Nanga Tebidah for nine years so that he correctly understands the condition of the congregation. From the research results it can be concluded that the congregation is God's partner in providing the growth of the Maranatha Topan GKE Church. Change must start with spirituality, mentality and then be followed by changes in praxis in ministry so that GKE Maranatha Topan experiences growth.

Keywords: GKE Maranatha Typhoon, Church Growth.
\end{abstract}

\begin{abstract}
Abstrak: Artikel ini mengulas masalah yang dialami di Gereja GKE Maranata Topan yang mengalami stagnan. Untuk itu penulis perlu mencari faktor-faktor yang menghambat pertumbuhan Gereja GKE Maranatha Topan. Metode penelitiaan yang digunakan penulis adalah metode eksploratif, wawancara dengan beberapa narasumber yang informasinya dapat dipercaya dan dipertanggungjawabkan sekaligus dengan metode kualitatif. Penulis juga pernah menjabat sebagai Ketua Resort di GKE Resort Nanga Tebidah selama sembilan tahun sehingga memahami secara benar kondisi dari jemaat tersebut. Dari hasil penelitian dapat disimpulkan bahwa jemaat adalah mitra Allah dalam memberikan pertumbuhan Gereja GKE Maranatha Topan. Perubahan harus dimulai dari spiritualitas, mentalitas lalu kemudian disusul dengan perubahan dalam praksis dalam pelayanan sehingga dengan demikian GKE Maranatha Topan mengalami pertumbuhan.

Kata Kunci: GKE Maranatha Topan, Pertumbuhan Gereja.
\end{abstract}

\section{Pendahuluan}

Pertumbuhan gereja sangat penting bagi sebuah gereja sehingga para pemimpin gereja dan warga jemaat berusaha dengan berbagai metode lewat program atau strategi yang ditetapkan bersama. Harapan gereja-gereja dengan adanya program yang telah ditetapkan, gereja dapat bertumbuh dengan baik, namun harapan tersebut belum sepenuhnya dialami 
secara khusus GKE Gereja Kalimatan Evangelis Jemaat Maranatha Topan, Resort Nanga Tebidah Kalimantan Barat. Fenomena ini melatarbelakangi penulis mengangkat topik Pertumbuhan Gereja sebagai suatu masalah serius terjadi yang dituangkan penulisan artikel ini. Persoalan jemaat GKE Maranatha Topan tersebut antara lain yaitu jumlah jemaat yang hadir dalam ibadah di gereja dan rumah tangga sangat minim, ketidakharmonisan antara majelis, antara anggota jemaat dan masih percaya kepada kekuaatan lain selain Allah. Dengan kata lain tanda-tanda pertumbuhan gereja secara kuantitas dan kualitas belum kelihatan.

Pertumbuhan Gereja tidak hanya diperankan oleh Pendeta, Penginjil, Vikaris, Penatua, dan Diaken tetapi juga oleh semua anggota jemaat. Gereja sebagai sebuah organisme yang hidup yang seharusnya terus bertumbuh dan berkembang di tengah-tengah dunia ini. ${ }^{1}$ Pertumbuhan Gereja tidak hanya dikerjakan oleh satu orang tetapi harus ada kerjasama dari seluruh komponen yang ada di dalamnya, termasuk warga jemaat dan tidak terlepas dari pada peran Roh Kudus dan merupakan inisiatif Allah dalam melakukan kehendakNya. Selama ini banyak paham yang beranggapan bahwa gereja dapat bertumbuh dengan baik bila gereja memiliki Pendeta yang bisa memainkan peran dalam segala bentuk pelayanan spiritual dan pembangunan jemaat. Masalah ini terjadi dalam jemaat GKE Maranatha Topan Resort Nanga Tebidah.

Melihat dari waktu masuknya GKE ke wilayah Desa Topan Nanga dari tahun 1972 hingga tahun 2018, mestinya GKE Maranatha Topan sudah bertumbuh, baik secara kuantitas maupun secara kualitas. Akan tetapi, pada kenyataan tidak demikian, GKE Maranatha Topan dalam pertumbuhannya baik secara kuantitas maupun kualitas masih sangat rendah. Faktor penghambat pertumbuhan Gereja GKE Maranatha Topan secara ringkas ketidakharmonisan antara jemaat, jemaat dengan majelis, lemahnya kepemimpinan gereja, ekonomi, praktik okultisme, dan kurang pembinaan kepada jemaat.

Dalam rangka mengatasi segala hambatan tersebut, peran dan tanggung jawab warga jemaat yang sangat menentukan bagi pertumbuhan gereja, demikian pula kerjasama yang baik antara majelis dengan hamba Tuhan, majelis dan jemaat. Oleh karenanya, gereja harus memiliki fokus yang tepat dalam pertumbuhan jemaat, yaitu dengan tidak hanya berfokus pada program gereja, namun dengan melakukan pendampingan secara pribadi dari pelayan (Pendeta atau Vikaris kepada tiap-tiap jemaat sehingga dapat mengenal pergumulannya). ${ }^{2}$ Dengan demikian gereja dapat mengambil sebuah langkah-langkah strategis baik dalam perubahan spiritualitas, emosional, mentalitas, dan reformasi dalam internal gereja untuk mengatasi segala hambatan pertumbuhan GKE Maranatha Topan. Jika gereja kehilangan fokusnya, maka pada akhirnya gereja tampak sebagai gereja yang vakum. Seharusnya, gereja itu disebut seperti sebuah organisme yang hidup, bukan mati. Itu sebabnya jika sebuah gereja sehat secara alami pasti mengalami pertumbuhan. Dengan demikian, berangkat dari latar

\footnotetext{
${ }^{1}$ Rick Werren, Pertumbuhan Gereja Masa Kini: Gereja yang Mempunyai Visi-Tujuan (Malang: Gandum Mas, 2000), 20.

2 Paulus Lie, Mereformasi Gereja (Yogyakarta: ANDI, 2010), 2.
} 
belakang masalah yang telah penulis paparkan di atas, maka yang menjadi rumusan masalah bagi penelitian ini adalah:

1. Bagaimana gambaran umum dan kendala Pertumbuhan Gereja Jemaat GKE Maranatha Topan?

2. Bagaimana pandangan para ahli tentang Pertumbuhan Gereja?

3. Bagaimana analisa Pertumbuhan Gereja di jemaat GKE Maranatha Topan?

4. Bagaiman langkah strategi misi Gereja dalam rangka pertumbuhan Gereja di jemaat GKE Maranatha Topan?

\section{Metode Penelitian}

Metode yang digunakan dalam penelitian ini adalah metode kualitatif deskriptif. ${ }^{3}$ Metode kualitatif deskriptif merupakan suatu metode dalam meneliti status kelompok manusia, suatu objek, suatu set kondisi, suatu sistem pemikiran ataupun suatu kelas peristiwa pada masa sekarang. ${ }^{4}$ Alasan penulis menggunakan metode kualitatif deskriptif adalah untuk menggali secara mendalam mengenai situasi dan keadaan jemaat GKE Maranatha Topan menggali masalah-masalah yang terjadi, aktifitas kehidupan mereka sehari-hari, sikap dan tingkah laku mereka, pengaruh serta sebab akibat yang terjadi dalam kehidupan berjemaat. Menurut Yosia Belo, "Penelitian kualitatif bertujuan untuk dapat memperoleh pemahaman kualitatif yang valid bagi topik yang dibahas". ${ }^{5}$ Tempat dan waktu penelitian dilaksanakan di Jemaat GKE Maranatha Topan pada bulan September 2018 - Desember 2018.

\section{Hasil dan Pembahasan}

\section{Gambaran Umum Gereja Jemaat GKE Maranatha Topan}

Jemaat GKE Maranatha Topan berada dalam wilayah Desa Topan Nanga. Desa Topan Nanga merupakan salah satu desa yang berada di Kecamatan Kayan Hulu, Kabupaten Sintang, Provinsi Kalimantan Barat. Desa Topan Nanga merupakan desa pemekaran dari desa Entogong, karena wilayah desa Entogong ini sangat luas dan penduduknya semakin padat. Desa Topan Nanga tepatnya berada di jalur sungai Kayan dengan luas wilayah 15,50 km2 dan diapit oleh Desa Nanga Tebidah (3km), desa Nanga Ungai (4 km) dan Desa Empakan (3 km). Jumlah penduduk di desa ini mencapai angka 581 jiwa dengan 161 kepala keluarga (kk). Jarak tempuh dari pusat Resort Nanga Tebidah ke jemaat GKE Maranatha Topan sekitar $3 \mathrm{KM}$ dengan kendaraan bermotor \pm 15 menit atau bisa melalui jalur sungai ketika musim

\footnotetext{
${ }^{3}$ Sugiyono, Cara Mudah Menyusun: Skripsi, Tesis dan Disertasi, (Bandung: Alfabeta, 2013), 30.

${ }^{4}$ Nazir, Metode Penelitian (Jakarta: Ghalia Indonesia, 2011), 186.

5 Belo, Yosia. "PENDIDIKAN AGAMA KRISTEN DALAM MATIUS 28: 19-20." Jurnal LUXNOS 1.2 (2020): 127-
} 133. 
hujan tiba. Sedangkan jarak desa Topan ke kota kabupaten Sintang ialah 73,7 km yang dapat ditempuh dengan kendaraan bermotor selama 7 (tujuh) jam. ${ }^{6}$

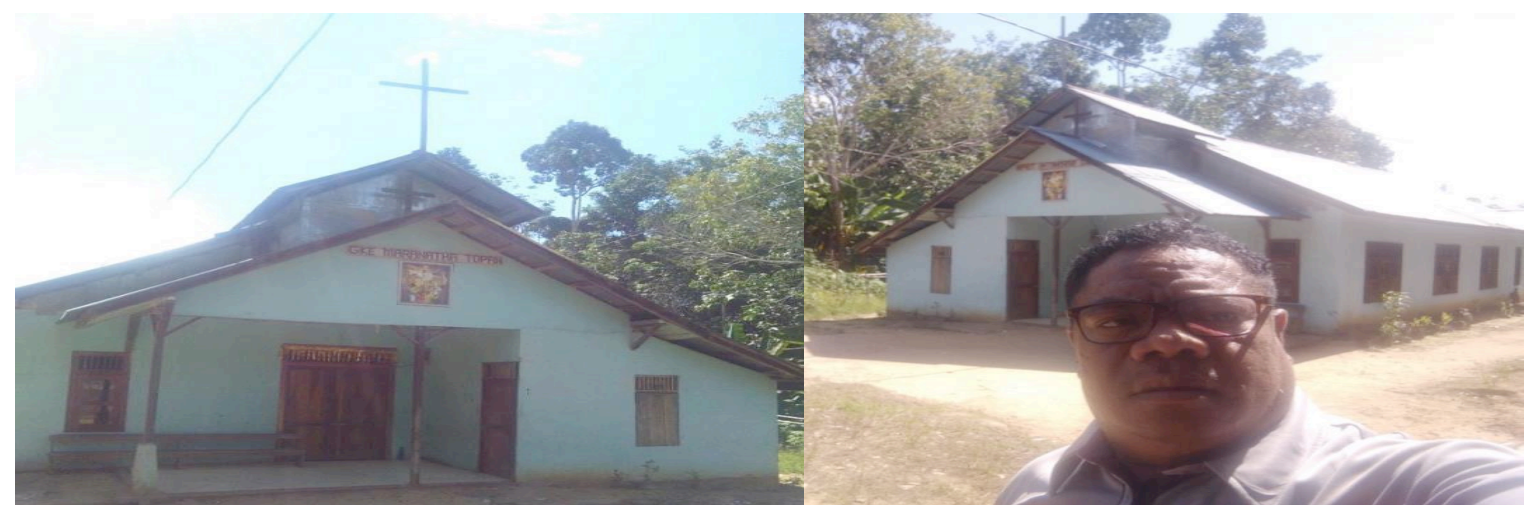

Bangunan Gereja GKE Maranatha Topan ～Ketua Resort GKE Nanga Tebidah Pdt. Osias Kause

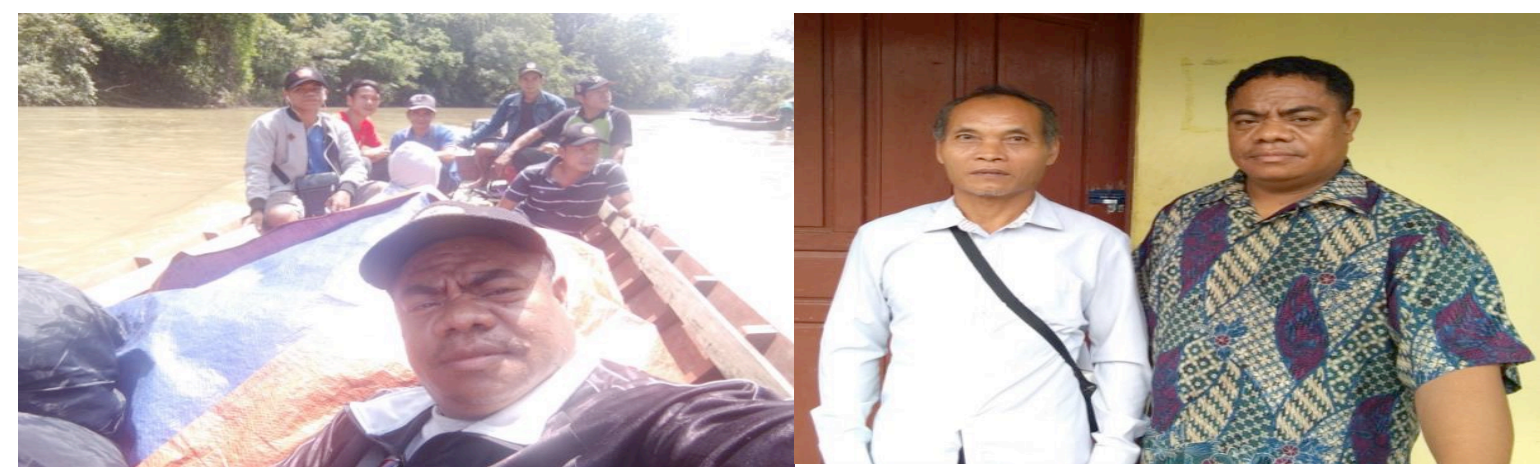

Perjalanan menuju Gereja GKE Maranatha Topan. Ketua Majelis GKE MT dan Ketua Resort GKE NTB

Penduduk desa Topan Nanga hampir semuanya memeluk agama Kristen (Protestan dan Katolik) yang terdiri dari 68 KK agama Kristen Protestan dan 93 KK agama Kristen Katolik. ${ }^{7}$ Penduduk desa Topan Nanga adalah mayoritas suku Dayak Kabahant. Berarti semua anggota jemaat GKE Maranatha Topan tergolong dalam suku Dayak Kabahant kecuali Pendeta, Vikaris dan Penginjil yang melayani di jemaat ini yang berasal dari suku lain seperti, suku Timor, suku Batak, dan suku Ambon ${ }^{8}$. Kemudian bahasa sehari-hari yang digunakan oleh masyarakat desa Topan Nanga yaitu bahasa Dayak Kabahant. ${ }^{9}$

Tabel 1. Data Jumlah Penduduk Desa Topan Nanga Tahun $2018^{10}$

\footnotetext{
${ }^{6}$ Dokumen, Kesekretariatan (Desa Topan Nanga, 2017), 7.

7 Ibid., 7.

${ }^{8}$ Hasil pengamatan, pada tanggal 11 September 2018.

${ }^{9}$ Hasil pengamatan, pada tanggal 11 September 2018.

10 Dokumen Sekretariatn Desa Topan Nanga 2018, hal, 10.
} 


\begin{tabular}{|c|c|c|c|c|c|c|c|}
\hline \multicolumn{2}{|c|}{ Jumlah KK } & \multicolumn{3}{|c|}{ Jumlah Penduduk } & \multicolumn{2}{|c|}{ Jumlah Jiwa } & \multirow{2}{*}{\begin{tabular}{|l} 
Keterangan \\
Luas
\end{tabular}} \\
\hline \multirow{2}{*}{\multicolumn{2}{|c|}{$161 \mathrm{KK}$}} & GKE & Katolik & Islam & $\mathrm{P}$ & $\mathrm{L}$ & \\
\hline & & 237 & 344 & - & 278 & 303 & \multirow{2}{*}{$\begin{array}{l}\text { Wilayah } \\
15,50 \mathrm{~km} 2\end{array}$} \\
\hline Total & $161 \mathrm{KK}$ & \multicolumn{3}{|c|}{581 Jiwa } & \multicolumn{2}{|c|}{581 Jiwa } & \\
\hline
\end{tabular}

Secara umum mata pencaharian masyarakat desa Topan Nanga adalah petani. Bercocok tanam sudah mereka lakukan sejak dahulu dan mereka mewarisi ini secara turun temurun dari nenek moyang mereka. Masyarakat Topan Nanga juga hidup dari menyadap karet yang hasilnya bisa di peroleh setiap hari meskipun sedikit. ${ }^{11}$ Di sisi lain, masyarakat desa Topan Nanga juga diperhadapkan dengan kesulitan ekonomi di mana harga barang pasar tidak sebanding dengan harga jual hasil pertanian masyarakat. Hal ini juga sangat berpengaruh dalam kehidupan jemaat GKE Maranatha Topan.

\section{Kendala Pertumbuhan GKE Maranatha Topan}

Melihat dari waktu masuknya GKE ke wilayah Desa Topan Nanga dari Tahun 1972 hingga tahun 2019 dengan usia 47 tahun, mestinya GKE Maranatha Topan sudah bertumbuh atau mengalami kemajuan, baik secara kuantitas maupun secara kualitas. Tetapi, pada kenyataan tidak demikian. GKE Maranatha Topan dalam pertumbuhannya baik secara kuantitas maupun kualitas masih sangat rendah. Terhambatnya pertumbuhan gereja ini karena adanya kendala-kendala yang terjadi dalam kehidupan jemaat dan Majelis Jemaat.

Menurut Dengok Purwanto, bagaimana Gereja Topan bisa berkembang jikalau masih ada anggota Majelis Jemaat yang berani melakukan pelanggaran yang bertentangan dengan norma-norma masyarakat atau pun agama. Padahal merekalah yang harus menjadi teladan bagi jemaat, ketika jemaat melakukan kesalahan Penatua dan Diakonlah yang seharusnya menegur, mengarahkan dan membimbing jemaat untuk hidup lebih baik sesuai dengan kehendak Tuhan. Tetapi malah yang terjadi justru sebaliknya mereka yang membawa jemaat untuk melakukan perbuatan yang tidak etis yang seharusnya tidak boleh dilakukan oleh seorang pelayan gerejawi,. ${ }^{12}$ Perbuatan tidak etis inilah yang menjadi penyebab sehingga jemaat malas beribadah bahkan tidak hadir beribadah jika majelis tersebut yang memimpin ibadah.

Kendala-kendala lain yang dialami oleh jemaat GKE Maranatha Topan adalah:

1. Konflik antar sesama anggota jemaat dewasa. Anak-anak dari orangtua jemaat yang memiliki masalah dengan sesama anggota jemaat atau dengan majelis tertentu dilarang oleh orangtuanya untuk mengikuti kebakitan Sekolah Minggu ${ }^{13}$.

\footnotetext{
11 Pnt.Marbudin, Wawancara dilakukan oleh Osias Kause di Topan, 15 November 2018.

12 Dengo Purwanto, sebagai Ketua Majelis GKE Maranatha Topan, Wawancara oleh Osias Kause, pada 8 September 2018.

13 Rusmina, sebagai Guru Sekolah Minggu, Wawancara oleh Osias Kause, pada 11 September 2018.
} 
2. Tidak ada hamba Tuhan yang melayani. Rendahnya semangat remaja pemuda dalam menghadiri kebaktian kategorial maupun kebaktian hari Minggu disebabkan yang melayani ialah oleh Penatua atau Diakon bukan Pendeta atau Vikaris. ${ }^{14}$ Majelis Jemaat GKE Maranatha Topan tidak berani meminta tenaga pelayan Pendeta atau Vikaris karena Gereja tidak mempunyai kemampuan finansial untuk memberikan kesejahteraan kepada hamba Tuhan yang melayani dan memang hingga pada saat ini gereja sedang mengalami krisis dibidang keuangan.

3. Persoalan ekonomi jemaat dan rendahnya pemahaman tentang ibadah. Pekerjaan warga Gereja pada umumnya sebagai petani dan penoreh karet sehingga sebagian besar jemaat memilih untuk bekerja di hari minggu daripada beribadah di Gereja. Pemahaman jemaat tentang pentingnya beribadah di gereja sangat kurang sehingga mereka beranggapan bahwa tidak ibadah atau ibadah juga sama hidup susah tidak pernah berubah. ${ }^{15}$

4. Lemahnya kerjasama antara anggota majelis dengan jemaat yang disebabkan oleh karena rendahnya tingkat kepercayaan warga jemaat terhadap pelayanan yang dilaksanakan oleh majelis. ${ }^{16}$

5. Ketua majelis dipimpin jemaat awam. Masalah yang terjadi terkait majelis yang dipimpin kaum awam ialah (a) Ketua majelis jemaat mempunyai pola pikir yang konservatif atau tertutup merasa diri "orang asli setempat" yang mengetahui secara persis selebuk-beluk situasi jemaat GKE Maranatha Topan sedangkan hamba Tuhan yang melayani bersifat tidak menetap artinya ialah sewaktu-waktu bisa dimutasi ke jemaat GKE lain. (b) Ketua majelis "merasa lebih tahu" sebab sebelum ia menjadi majelis ia lebih dulu menjadi aktif melayani sehingga dengan demikian ia merasa diri mengerti dalam membuat kebijakan strategis menyangkut pertumbuhan GKE Maranatha Topan. (c) Ketua majelis tersebut merasa disaingi dengan hamba Tuhan, apalagi hamba Tuhan tersebut pendatang bukan orang Dayak dan bukan orang asli GKE. ${ }^{17}$

6. Hamba Tuhan kurang berani melakukan terobosan. Hamba Tuhan kurang berani untuk melakukan terobosan bagi kemajuan Gereja. Hal ini disebabkan karena dalam satu gereja, sesama anggota jemaat tidak akur dan tidak saling mendukung termasuk dari anggota majelis dan juga hamba Tuhan. Akan tetapi, tugas sebagai hamba Tuhan biasanya memilih untuk dipihak yang netral. Bahkan meskipun dalam posisi yang netral hamba Tuhan terkadang memiliki kesalahan dimata jemaatnya sebab dalam pikiran mereka jangan-jangan hamba Tuhan ini pro-dengan kelompok yang satu dan kontra terhadap kelompok yang lain. ${ }^{18}$

7. Tingkat pendidikan jemaat masih rendah. Apakah tingkat pendidikan mempunyai implikasi terhadap pertumbuhan Gereja? Jawabnya iya. Secara keseluruhan tingkat

\footnotetext{
${ }^{14}$ Mikha Sebagai Ketua SPPR, Wawancara oleh Osias Kause, pada 8 September 2018.

15 Pengamatan, Osias Kause selama melayani di jemaat GKE Maranatha Topan hingga tahun 2018.

16 Darius Eder, Wawancara dilakukan oleh Osias Kause,di Topan, pada 7 September 2018.

17 Vic.Wahyu, Wawancara di lakukan oleh Osias Kause, di Nanga Tebidah, pada 15 Oktober 2018.

18 Hasil Pengamatan selama melayani di Resort Nanga Tebidah, 2018.
} 
pendidikan warga jemaat di GKE Maranatha Topan yang rata-rata umumnya lulusan SD, SMP sedangkan lulusan SMA sedikit. Jemaat yang hanya memiliki pendidikan SMP, SMA yang mempunyai pemikiran yang kritis terhadap kondisi GKE Maranatha Topan. Oleh karenanya tidak heran bahwa masalah pendidikan jemaat sangat mempengaruhi pertumbuhan Gereja GKE Maranatha Topan sebab sebuah perubahan gereja harus dimulai dari perubahan pola pikir jemaatnya atau dari setiap individu-individunya. ${ }^{19}$

8. Keterlibatan jemaat GKE Maranatha Topan terhadap praktik Okultisme. ${ }^{20}$

9. Jemaat kurang diperlengkapi dalam pelayanan. Berdasarkan pengamatan Darius Eder, perlu adanya kesadaran khususnya bagi Penatua, Diakon dan pengurus kategorial jemaat GKE Maranatha Topan untuk mengadakan pembinaan. Sebab jemaat ini boleh dikatakan sudah lama menjadi Kristen tetapi belum memahami dan mempraktekkan kehidupan sebagai orang Kristen. ${ }^{21}$

\section{Pandangan Para Ahli Tentang Teori-Teori Pertumbuhan Gereja}

Pertumbuhan gereja merupakan kehendak Tuhan, bahwa gereja yang sehat seharusnya memiliki pertumbuhan yang baik. Mc. Gavran berpendapat bahwa pertumbuhan gereja bukan dititikberatkan pada banyaknya jumlah missionaris atau besarnya jumlah dana misi menurut angka-angka statistik dan lain-lain, melainkan dititikberatkan pada pertumbuhan rohani seseorang yang ditandai dengan pertobatan. ${ }^{22}$ Sedangkan Nathanael Chao mendasari keyakinannya dari firman Tuhan yang terdapat dalam Matius 13:31-33 dan Lukas 13: 18-21 mengenai perumpamaan tentang biji sesawi dan ragi. Dalam hal ini gereja bertumbuh dari kecil menjadi besar karena di dalam gereja ada Tuhan. ${ }^{23}$

C. Peter Wagner seorang pakar gerakan pertumbuhan gereja juga menyatakan keyakinannya bahwa pertumbuhan gereja adalah merupakan kehendak Allah. ${ }^{24}$ Hal ini senada dengan Rick Warren. Ia menambahkan bahwa tugas manusia hanya mengikuti gerakan Allah dalam pertumbuhan Gereja-Nya. Ia menggunakan contoh berselancar untuk menjelaskan bagaimana Allah yang membuat gereja bertumbuh dan tugas manusia dalam mengikuti gerakan Allah dalam pertumbuhan gereja-Nya. ${ }^{25}$ Pengertian pertumbuhan gereja seharusnya ialah pertumbuhan secara kuantitatif dan kualitatif. Kedua pertumbuhan ini tidak boleh dipisahkan satu dengan lainnya tetapi harus beriringan dan saling melengkapi. ${ }^{26}$

Pendeta Nathanel Chao, pertumbuhan gereja harus diukur dengan:

1. Jumlah (banyaknya) anggota yang berbakti dalam kebaktian.

19 Ibid.

${ }^{20}$ Ev. Yosep Kay, Wawancara di lakukan oleh Osias Kause,di Topan, pada 21 Oktober 2018.

${ }^{21}$ Darius Eder, Wawancara di lakukan oleh Osias Kause, di Topan, pada 7 November 2018.

${ }^{22}$ Mc. Gavran, Back to Basic to Basic in Church Growth (Wheaton: Tyndale, 1981),22.

${ }^{23}$ Nathanael Chao, "Bahan Ceramah Pertumbuhan Gereja di STT Iman Jakarta" (Jakarta, 2000), 15.

${ }^{24}$ C. Peter Wagner, Memimpin Gereja Anda Agar Bertumbuh (Harvest Publication House (Jakarta: Harvest Publication House, 1995), 19.

${ }^{25}$ Werren, Pertumbuhan Gereja Masa Kini: Gereja yang Mempunyai Visi-Tujuan, 17.

26 Ibid., 54-55. 
2. Jumlah yang dibaptis semakin banyak maka Gereja dapat dikatakan.

3. Semakin banyak anggota jemaat yang terlibat dalam pelbagai pelayana atau aktivitas gereja semakin menujukkan pertumbuhan gereja itu.

4. Berapa banyak aktivitas yang diadakan oleh gereja itu, baik yang ke dalam terlebih bagi masyarakat.

5. Jumlah pos Pekabaran Injil yang Bertambah. Fokus pertumbuhan gereja harus selalu terarah ke luar. ${ }^{27}$

Dalam memahami pengukuran pertumbuhan gereja, Griffiths dalam bukunya Gereja dan Panggilannya Dewasa membuat kriteria tentang pertumbuhan gereja secara kuantitatif maupun kualitatif sebagai berikut:

1. Pertumbuhan dalam jumlah orang-orang Kristen (Kis. 2:41; 5:14,6,7).

2. Pertumbuhan dengan jumlah jemaat (kis 16:5)

Sedangkan pertumbuhan gereja secara kualitatif dapat dilihat dari:

1. Pertumbuhan dalam kasih dan hubungan antar pribadi sebagai sesama anggota Gereja (1 Tes 4:10, 1 Pet 1:22, 4, 8).

2. Pertumbuhan dalam kerjasama sebagai suatu tubuh Kristus (Ef 4:16).

3. Pertumbuhan dalam latihan dan pengiriman guru-guru (Kis 11:25, 13:1-2; 15:35) Artinya mengirimkan para pekerja dari kalangan orang-orang yang sudah terlatih untuk mendirikan gereja di mana-mana.

4. Pertumbuhan dalam kekudusan dan gaya hidup yang indah ( 1 Kor 3:18, Ef. 5:27).

5. Gereja tumbuh dengan berbuat bagi orang-orang lain dalam masyarakat secara keseluruhan (1 Pet 2:12, 1 Tes 1:8).

6. Orang-orang Kristen harus menekankan para pemimpin gereja mereka untuk mengajar (Kol 1:28, 1 Kor 14:20).

7. Pertumbuhan dalam realitas ibadah bersama (Ef 5:18-20, Kol. 3:15-16). ${ }^{28}$

Peter Wagner mengatakan: "Seringkali saya berpapasan dengan seseorang yang berkata, "Gereja kami hanya tertarik pada kualitas, dan bukan pada kuantitas". Saya akan lebih suka bila orang tersebut berkata, "Gereja kami tertarik pada kualitas sama halnya seperti kepada kuantitas". Saya setuju dengan kalimat yang terakhir, tetapi saya tidak yakin kita perlu untuk menetapkan kualitas melawan kuantitas. Kita bisa dan seharusnya memiliki keduanya. ${ }^{29}$

Wagner dalam bukunya Memimpin Gereja Anda agar Bertumbuh mengutip pandangan Richard L.Gorsuch dari Fuller Seminary School of Pschology bahwa alat pengukur yang pantas dijadikan sebagai alat pengukur kualitas sebuah Gereja menurut adalah:

\footnotetext{
${ }^{27}$ Chao, "Bahan Ceramah Pertumbuhan Gereja di STT Iman Jakarta", 15.

${ }^{28}$ Michael Griffifth, Gereja dan Panggilannya Dewasa ini (Jakarta: BPK Gunung Mulia, 1991), 80-100.

29 Ibid., 24-25.
} 
1. Para anggota gereja bertambah pengetahuan dalam pengajaran Alkitab.

2. Para anggota menghabiskan waktu mereka setiap harinya melakukan ibadah secara pribadi.

3. Para anggota secara teratur mengambil bagian dalam kebaktian-kebaktian yang disusun gereja.

4. Para anggota secara teratur mencoba untuk berbagi iman mereka akan Yesus Kristus kepada orang-orang yang belum percaya.

5. Kaum awam di gereja juga ikut terlibat dalam berbagai macam pelayanan.

6. Para anggota memberikan sebagaian dari pendapatan mereka untuk gereja.

7. Hubungan pribadi dalam persekutuan makin bertumbuh.

8. Para anggota secara umum memperlihatkan gaya hidup Kristus.

9. Para anggota gereja menganggap keterlibatan mereka dengan gereja sebagai sebuah pelayanan kepada Allah.

10. Para anggota melayani satu sama lain di luar lingkungan gereja. ${ }^{30}$

Kemudian ada peneliti lainnya yaitu Christian A Schwarz yang menemukan delapan karakteristik untuk menunjukkan bahwa ada kaitan antara kualitas kehidupan jemaat dengan gereja:

1. Gereja yang bertumbuh yaitu ketika pemimpin memiliki visi dan kemampuan untuk menghasilkan para pemimpin baru.

2. Para pelayan gereja harus mengetahui karunia jemaat dan menempatkan mereka pada posisi pelayanan yang dipercayakan.

3. Gereja harus fokus terhadap pertumbuhan rohani jemaat. Sebab hubungan yang intim dengan Tuhan adalah kunci dari pertumbuhan gereja yang alami.

4. Diperlukan struktur yang tepat guna agar gereja semakin bertumbuh.

5. Ibadah yang inspiratif agar jemaat dapat berjumpa dengan Allah dalam Ibadah.

6. Perlunya Kelompok kecil dalam Gereja agar dapat mendukung pertumbuhan rohani.

7. Penginjilan haruslah dengan ketulusan untuk menjawab kebutuhan mereka.

8. Gereja yang bertumbuh ditandai dengan kasih yang tulus, keharmonisan dan kedamaian seperti yang dikehendaki Allah. ${ }^{31}$

\section{Analisa Pertumbuhan Gereja di jemaat GKE Maranatha Topan?}

Pada bagian ini penulis akan mengindentifikasikan faktor-faktor yang menghambat pertumbuhan gereja serta menganalisis dengan lebih rinci sebagai berikut:

\section{Sekolah Minggu}

Bagi konteks jemaat GKE Maranatha Topan justru mengalami hambatan dalam memajukan pelayanan Sekolah Minggu di GKE Maranatha Topan. Berdasarkan jumlah anak sekolah minggu di Gereja tersebut sebanyak 60 anak dan jumlah Guru Sekolah Minggu

30 Ibid., 26-27.

31 Christian A Schwarz,: http://gsjarks.org/2020/02/11/pertumbuhan-gereja-yang-alamiah/. Diakses 28 Oktober 2018, pukul 20:WIB. 
sebanyak 4 orang. Namun yang hadir dalam kebaktian sekolah minggu sebanyak 15 anak. ${ }^{32}$ Sejauh ini Guru Sekolah Minggu selalu mengadakan perkunjungan untuk mengajak dan mengingatkan anak-anak mengikuti kebaktian sekolah minggu. Berdasarkan pengakuan dari Guru Sekolah Minggu, anak-anak tersebut selalu mengiyakan setiap kali Guru Sekolah Minggu mengajak ke gereja ikut kebaktian sekolah minggu. Tetapi faktanya, hari Minggu mereka tidak datang. Menurut Rusmina sebagai Guru Sekolah Minggu setempat bahwa mereka tidak didukung oleh orangtuanya untuk mengikuti kebaktian sekolah minggu, sebab orangtuanya juga tidak pernah mengikuti ibadah umum maupun ibadah-ibadah lainnya. ${ }^{33}$ Sikap dan cara berpikir orangtua dari anak Sekolah Minggu tersebut tidak sejalan dengan sabda Tuhan Yesus yang berkata: "Biarkan anak-anak itu datang kepada-Ku, jangan menghalang-halangi mereka, sebab orang-orang yang sperti itulah yang empunya Kerajaan Allah" (Mrk. 10:14).

Berdasarkan hasil penelitian di atas, maka penulis menarik sebuah kesimpulan bahwa pada dasarnya anak merupakan tanggung jawab orangtua, selain itu pun masa depan anak juga sangat ditentukan dari bagaimana orangtua tersebut mendidik dan mengasuh anak tersebut. Dalam kaitan ini penulis hendak menganalisa bahwa persoalan yang terjadi ini ialah masalah pribadi orangtua dengan sesama anggota Gereja yang kemudian berimbas terhalangnya seorang anak untuk memenuhi kebutuhan rohaninya. Kenyataannya tidak ada kasih maupun kerjasama sebagai tubuh Kristus untuk berpikir bagaimana jemaat Tuhan dapat bertumbuh imannya dalam Kristus. Ketika orangtua tidak bisa bijaksana memisahkan antara masalah pribadi dengan tanggungjawab orangtua terhadap kebutuhan anak terhadap hal-hal rohani maka ini hanya akan menambah persoalan baru bagi orangtua tersebut. Jikalau kebutuhan rohani anak tidak terpenuhi maka membuka ruang bagi pengaruh-pengaruh negatif untuk masuk dan mengendalikan kehidupan dari anak tersebut. Sudah pasti ini berdampak bagi masa depan penerus GKE Maranatha Topan.

\section{Remaja dan Pemuda}

Menurut Mikha penyebab utama remaja pemuda memilih tidak mengikuti persekutuan ibadah SPPR karena yang melayani mereka bukan Pendeta,Vikaris atau Penginjil tapi Penatua atau Diakon yang tidak bisa jadikan sebagai teladan. Bagi remaja dan pemuda jika ada tenaga pelayan khusus melayani di gereja tersebut mereka lebih bersemangat untuk mengikuti ibadah dan juga melakukan kegiatan yang diprogramkan. Hal tersebut disebabkan karena tidak ada kemampuan untuk memberikan kesejahteraan kepada hamba Tuhan yang melayani. Bagi penulis, untuk mengatasi masalah ini bukan hanya tanggung jawab dari gereja setempat tetapi ini juga merupakan pergumulan Resort GKE Nanga Tebidah, bagaimana caranya agar ada pelayan yang dapat ditempatkan dan bisa menetap di jemaat Topan.

\section{Kondisi Jemaat Dewasa}

\footnotetext{
32 Hasil Pengamatan, pada tanggal 10 September 2018.

33 Rusmina,Wawancara dilakukan oleh Osias Kause, di Topan, pada 6 November 2018.
} 
Realita yang terjadi di dalam jemaat GKE Maranatha Topan yaitu ada perselisihan antar keluarga, sampai kepada perselisihan antara kelompok. Hal ini yang membuat kondisi internal Gereja GKE Maranatha Topan mengalami polarisasi atau berkelompok-kelompok. Masalah inilah yang menyebabkan banyak jemaat memilih untuk tidak datang beribadah di gereja karena merasa terganggu ketika beribadah dengan kehadiran orang yang dianggap sebagai musuhnya.

Bagi penulis menjauhkan diri dari peribadatan di gereja bisa dikategorikan secara tidak langsung sebagai sikap menjauhkan diri dari Tuhan dan ini hanya akan menambah beban persoalan bagi beberapa anggota jemaat yang memilih menjauhkan diri dari ibadah di gereja. Karena bagi penulis beberapa jemaat yang memilih tidak hadir dalam kebaktian minggu wajib mempunyai pengertian yang benar bahwa ibadah di hari minggu sangat penting pengaruhnya bagi pertumbuhan iman dan perubahan sikap dan perilaku seseorang.

\section{Kondisi Majelis Jemaat}

Dalam sejarah kemajelisan GKE Maranatha Topan, beberapa majelis gereja setempat pernah melakukan perbuatan yang tidak berkenan di hadapan Tuhan dan di hati jemaat baik dalam hal moral dan etika termasuk dalam hal keuangan Gereja yang dikelolah dengan sikap yang tidak jujur dan transparan. Perbuatan yang dinilai tidak pantas ini membuat paradigma jemaat menjadi seolah tidak percaya dengan kepengurusan dan pelayanan majelis setempat sebagai orang-orang yang telah dipercayakan oleh jemaat untuk memimpin penatalayanan GKE Maranatha Topan. Tidak ada kekompakan, yang disebabkan karena masalah pribadi dengan sesama anggota majelis lain sehingga meluas menjadi masalah antar keluarga.

Berikutnya, kemajelisan jemaat dalam melaksanakan tugas pelayanannya tidak maksimal artinya tidak menjalankan mandat fungsional mereka dengan baik dan bertanggungjawab. Majelis Jemaat setempat masih memiliki mentalitas hamba Tuhan sentris. ${ }^{34}$ Sebagai contoh kongkrit: sekretaris majelis sebagaimana tugasnya mengurus dan mengkoordinir segala keperluaan gereja, malah hampir semuanya hamba Tuhan yang kerjakan, dan sekretaris gereja tugas yang dipahaminya hanya sebatas melakukan tandatangan.

Penulis mengamati kalau ketua majelis dipimpin oleh jemaat awam yang bukan berpendidikan teologi ini sebuah kecelakaan bagi gereja tersebut hal ini terbukti sepanjang sejarahnya ketua majelis tersebut tidak mempunyai kecakapan dalam mengorganisir atau menggerakan jemaat GKE Maranatha Topan agar visi dan misi sinode GKE dapat terwujudnyatakan dalam konteks di mana GKE Maranatha Topan berada yaitu di desa Topan. Bagi penulis hal tersebut harus segera dikerjakan agar Gereja GKE Maranatha Topan segera mewujudkan realisasinya. 


\section{Hamba Tuhan}

Walaupun pertumbuhan gereja sebenarnya harus di mulai dari seorang Gembala namun hal ini tidak mampu ditunaikan dengan baik sebab sejauh yang penulis ketahui bahwa dalam sejarahnya para hamba Tuhan yang pernah melayani di GKE Maranatha Topan kurang memiliki keberanian dalam melakukan perubahan. Hal ini disebabkan karena terjadinya kompleksitas masalah di Gereja GKE Maranatha Topan. Dengan berbagai masalah yang terjadi setiap hamba Tuhan yang pernah melayani di GKE Maranatha Topan tidak berani melakukan sebuah terobosan yang disebabkan perasaan takut gagal dan takut mengambil resiko. Inilah suatu realita sebenarnya yang terjadi di jemaat GKE Maranatha Topan, dimana hamba Tuhan yang dipercayakan kurang termotivasi untuk mengembangkan gereja demi pertumbungan jemaat di GKE Maranatha Topan ke arah yang lebih baik dari sebelumnya.

\section{Pendidikan}

Tingkat pendidikan yang rendah ini menjadi salah satu faktor yang mempengaruhi gereja yang berada di desa Topan yakni GKE Maranatha Topan. Jemaat tersebut bisa dibilang tidak mempunyai visi dan juga kesadaran untuk memajukan dan mengembangkan gereja dari segala bidang. Jemaat tersebut sejak lama hidup pada posisi status quo yang artinya mempertahankan keadaan sekarang yang tetap seperti keadaan sebelumnya.

Hal inilah yang membuat setiap orang yang dipercayakan menjadi pengurus majelis gereja kurang memahami secara benar tugas dan fungsinya dalam organisasi Gereja. Mereka belum ada keinginan untuk belajar berorganisasi dan memahami fungsi dari setiap bagian dari organisasi. Sehingga pada akhirnya majelisnya hanya menyerahkan sepenuhnya pekerjaan penatalayanan kepada hamba Tuhan yang sedang bertugas di jemaat setempat karena dianggapnya lebih mengerti dan memahami tata gereja, organisasi, liturgi, pastoral, teologi pelayanan Gereja, dll. Inilah menjadi salah satu faktor yang mempengaruhi Gereja GKE Maranatha Topan tidak mengalami pertumbuhan. Jika jemaat sejak awal menerima bekal pendidikan secara memadai maka pastilah pola pikirnya akan berubah dan perubahan ini jelas mempengaruhi dalam upaya memajukan pertumbuhan Gereja.

\section{Okultisme}

Salah satu penyebab lambatnya pertumbuhan gereja GKE Maranatha Topan adalah masalah okultisme. Dalam sebuah buku karangan Eric J. Dingwal dan John Langdon Davies okultisme berawal dari kehausan kepastian akan sesuatu hal yang belum diketahui oleh manusia. Dengan alasan bahwa agama tidak mampu memberikan jawaban atas "kehausan" itu. Maka manusia beralih kepada "alam gaib", di mana ada sesuatu kuasa yang tidak nampak atas pengelihatan manusia biasa. ${ }^{35}$ Kepercayaan terhadap setan, benda gaib, pergi ke tempattempat keramat menjadi semacam sesuatu yang lumrah terjadi di desa Topan, namun yang

35 Erick J. Dingwall \& John Langdon Davies, Alam Gaib (Surabaya: Pustaka Progresif, 1964), 20-22. 
memprihatikan bahwa banyak warga jemaat GKE Maranatha Topan, ketika sakit dan menghadapi masalah lainnya, lebih percaya dan meyakini bahwa praktik perdukunan adalah solusi tepat dalam menghadapi dan mengatasi beragam bentuk persoalan hidup.

Bagi penulis hal perilaku tersebut bisa menjadi hambatan bagi pertumbuhan Gereja sebab bagi Richard L. Goursuch mengatakan jemaat yang bertumbuh terlihat dari gaya hidup jemaat seperti Kristus. ${ }^{36}$ Sudah semestinya jemaat GKE Maranatha Topan menyerahkan persoalan hidupnya kepada Kristus yang kuasanya jauh melebihi kuasa-kuasa kegelapan: maka tidak boleh memberi ruang sedikit pun pada kuasa kegelapan.

\section{Kurangnya Pembinaan dalam Jemaat}

Kurangnya perhatian terhadap pembinaan dalam jemaat akan menjadi penyebab terhambatnya pertumbuhan suatu gereja. Namun harus disadari bahwa kepemimpinan GKE Maranatha Topan belum mampu merealisasikan dengan baik oleh karena jemaat kurang diperlengkapi dalam pelayanan diantaranya: (1) Majelis jemaat dan guru sekolah minggu kurang mendapatkan pembinaan yang memadai dalam bidang pengajaran firman Tuhan bagaimana mungkin bisa menyampaikan renungan firman Tuhan dengan baik. Akibat dari kurangnya pembinaan kepada majelis dalam ketrampilan berkhotbah, ketika ditugaskan untuk menyampaikan khotbahnya biasa digunakan menyerang pihak atau kelompok tertentu atau menyampaikan hal-hal yang bersifat moralitas dan etika. Bagi penulis, Alkitab tidak pernah memerintahkan pengkhotbah untuk memakai ayat firman Tuhan untuk menyerang pihak atau pun kelompok tertentu. (2) Persoalan berikutnya yang sama pentingnya ialah jemaat kurang diperlengkapi bagaimana menjadi liturgos yang baik. Penulis meyakini bahwa pujian yang dinyanyikan ketika kebaktian umum maupun kebaktian keluarga merupakan salah satu sarana penting bagi pertumbuhan iman jemaat.

\section{Langkah Strategi Misi Gereja Dalam Rangka Pertumbuhan Gereja di Jemaat GKE Maranatha} Topan

\section{1) Pembenahan Organisasi}

Jemaat GKE Maranatha Topan harus memiliki sebuah kesadaran bahwa salah satu pertumbuhan dari sebuah gereja sangat ditentukan dari peran aktif dari majelis setempat, sebab gereja memerlukan sebuah sistem organisasi untuk mengatur agar masing-masing orang yang telah dipercayakan oleh jemaat dapat menjalankan tugasnya dengan baik sesuai dengan jabatannya.

Langkah awal untuk mengatasi masalah tersebut ialah diperlukan sebuah sikap perubahan mentalitas dari majelis setempat untuk berubah artinya tidak mungkin ada sebuah perubahan dari dalam Gereja jika mentalitas lama yang tidak produktif masih dipertahankan. Jadi tidak jadi alasan bagi majelis untuk melegitimasi bahwa konteks pedesaan di kab. Sintang

${ }^{36}$ C. Peter Wagner, Memimpin Gereja Anda Agar Bertumbuh..., 26-27. 
menjadi salah satu faktor utama bagi Gereja GKE Maranatha Topan untuk tidak mengalami sebuah kemajuan. Langkah berikutnya, hamba Tuhan setempat harus berkoordinasi dengan Resort Nanga Tebidah sebagai mitra dalam melakukan pembinaan secara berkala kepada jemaat, penatua dan diakon agar semakin memahami dan mengerti peran mereka dalam bergereja.

\section{2) Pengefektifan Kepemimpinan}

Pengefektifan kepemimpinan yang penulis usulkan disini:

a. Sebaiknya hamba Tuhanlah yang menempati posisi sebagai (Ketua Majelis jemaat GKE Maranatha Topan) sebab mereka adalah orang yang dipersiapkan untuk memimpin gereja serta memikirkan pengembangan gereja baik jangka pendek maupun jangka panjang,

b. Meningkatkan kemampuan diri sebagai pemimpin dengan cara terus belajar, belajar mempercayai orang lain, dll.

c. Menyiapkan, melengkapi dan melatih sebanyak-banyak jemaat dalam pelayanan sesuai dengan karunianya masing-masing, termasuk dalam pelayanan kepemimpinan dan penginjilan. ${ }^{37}$ Wagner mengemukakan bahwa "Pendeta James Kennedy telah sejak lama menyadari bahwa pertumbuhan dalam gerejanya terhambat karena jemaat memiliki sikap bahwa pendeta yang harus melakukan semua kegiatan pelayanan. Pendeta James Kennedy berkata: "menyuruh pendeta melakukan semua kegiatan pelayanan merupakan bidat terbesar yang telah mewabahi gereja". ${ }^{38}$

d. Merekrut pelayan penuh waktu dengan terencana dan menempatkan mereka pada bidang yang sesuai dengan talenta dan karunianya.

\section{3) Pengoptimalan Sumber Daya yang Tersedia}

Pada bagian ini penulis memandang bahwa yang dipersoalkan bukan pada ketersediaan sumber dana yang berlimpah atau terbatas, tetapi pada apakah sumber dana yang tersedia sudah dioptimalkan atau belum. Karena itu dalam pemilihan bendahara majelis GKE Marantha Topan haruslah yang dikenal jemaat atau pun warga desa Topan sebagai orang jujur dan dapat dipercaya bukan yang terdekat secara personal. Kemudian langkah yang ditawarkan untuk mengatasi masalah keuangan di gereja tersebut ini ialah GKE Resort Nanga Tebidah masih memberikan bantuan dana kepada jemaat-jemaat di wilayah Resort Nanga Tebidah yang betul-betul secara keuangan sangat memprihatinkan seperti salah satunya ialah di GKE Maranatha Topan. Hal ini senada dengan apa yang pernah dilakukan oleh rasul Paulus dimana ia menasihatkan kepada jemaat-jemaat di Galatia untuk memberikan bantuan kepada jemaat di Yerusalem yang mengalami kekurangan (1 Kor. 16:1-4).

\footnotetext{
37 Stephen R Covey, Kepemimpinan yang Berprinsip (Jakarta: Binarupa Aksara, 1997), 29-37.

${ }^{38}$ C. Peter Wagner, Gereja Saudara Dapat Bertumbuh (Malang: Gandum Mas: Penerbit Gandum Mas, 1997), 1920.
} 


\section{4) Peningkatan Keberanian Menangkap Kesempatan}

Ketakutan untuk memanfaatkan setiap kesempatan yang ada jelas tidak pernah menghasilkan sesuatu, dan hal ini jauh lebih buruk daripada gagal setelah berusaha. Dari pengalaman penulis sepanjang pelayanan di Gereja GKE kesan yang paling yang menonjol dari terhambatnya pertumbuhan gereja ini adalah kurang beraninya para hamba Tuhan (Vikaris dan Penginjil) menangkap kesempatan-kesempatan yang ada. Baik dalam hal peningkatan kerohanian dan penambahan wawasan, maupun kesempatan pengembangan gereja. Mempertimbangkan dan memperhitungkan segala kemungkinan dalam memulai sesuatu yang baru tentu sangat diperlukan. Tetapi perhitungan dan pertimbangan yang terlalu bersifat asumtif dan pesimistis menyebabkan fakta-fakta yang ada di tempat pelayanan seharusnya disikapi dengan optimis bukan diabaikan. Hal ini juga terjadi bagi setiap Hamba Tuhan yang ditugaskan di GKE Maranatha Topan mengingat kondisi jemaatnya yang mempunyai persoalannya yang cukup kompleks.

Sehubungan dengan itu, pola pikir hamba Tuhan yang selama ini "terlalu kehatihatian" sudah seharusnya diubah dengan pola pikir "jangan takut mencoba". Prinsip kegagalan merupakan keberhasilan yang tertunda perlu menjadi prinsip bagi para Hamba Tuhan di GKE Maranatha Topan. Apa yang mungkin dilakukan dengan kondisi saat ini, lakukanlah segera demi pertumbuhan jemaat GKE Marantaha Topan.

\section{5) Perkunjungan Pastoral:}

Dalam sebuah wawancara penulis dengan Darius, S.Pd.K, ia adalah seorang Diakonos di GKE Maranatha Topan, ${ }^{39}$ dan juga guru agama di SD Negeri Topan. Dalam isi percakapannya Darius sedikit menceritakan pengamatannya kepada penulis yang sejak 7 tahun belakangan ini sejak GKE Resort Nanga Tebidah membuat sebuah tradisi baru yakni ibadah kunjungan ke rumah-rumah dalam rangka doa atas upacan syukur paskah, gawai dan juga Natal. Oleh karena itu dapat disimpulkan dalam satu tahun berarti ada 3 kali kegiatan perkunjungan itu dilakukan. Dalam perkunjungan tersebut mereka memberikan pokok doadoanya kepada hamba Tuhan untuk didoakan sekaligus juga memberikan motivasi kepada anggota keluarga yang sedang diperhadapkan sebuah masalah. Ketika itu ketua Resortnya Pdt. Osias Kause menghimbau kepada seluruh hamba Tuhan yang melayani di Resort Nanga Tebidah agar tidak boleh melewatkan satu rumah pun kecuali pihak keluarga tersebut saat itu sedang bepergian. Secara khususnya di GKE Maranatha Topan yang jumlah 98 KK jika itu semua dikunjungi maka bisa memakan waktu 3 hari lamanya. Dari pengamatan Darius, ia katakan bahwa dalam perkunjungan itu bukan hanya mendoakan tetapi juga memperat jalinan silaturahmi antara Hamba Tuhan kepada jemaatnya. Respon jemaat sejak tradisi ini diberlakukan di Resort Nanga Tebidah secara khusus di GKE Maranatha Topan mereka

\footnotetext{
39 Wawancara Diakon Darius, S.Pd.K, Guru Agama di SD Topan Kamis 6 Mei 2019 pukul 09.00 WIB.
} 
(jemaat) memberikan respons dan komentar yang sangat positif sebab jemaat merasa diperhatikan dan dipedulikan oleh Hamba Tuhan yang melayani bahkan disaat itu ada jemaat tertentu yang sebelumnya sangat tertutup dengan masalahnya pada akhirnya berani terbuka untuk menceritakan masalah yang mereka hadapi kepada Hamba Tuhannya dan disaat yang sama juga berdampak bagi tingkat kehadiran kebaktian keluarga dan kebaktian umum di hari minggu.

Selanjutnya penulis melakukan wawancara kepada Vic. Wahyu ${ }^{40}$ yang saat ini melayani di Resort Tebidah. Ia katakan bahwa dengan dilakukan kunjugan ibadah doa ke rumah-rumah jemaat di GKE Marantha Topan ternyata berdampak bagi meningkatnya kehidupan spiritualitas jemaatnya dan itu terlihat dari perubahan perilaku hubungan antar jemaat dan juga ikut mendukung penuh segala bentuk pelayanan di GKE Maranatha Topan. Vic. Wahyu katakan hal ini tidak ditemukan di resort-resort lain hanya ada di resort Nanga Tebidah. Tanpa pilih kasih, semua jemaat di kunjungi semua. Ini sesuatu yang istimewa yang terjadi di GKE Resort Nanga Tebidah. Harapan dari Vic. Wahyu kunjungan ibadah doa ke rumah-rumah yang dilakukan satu tahun tiga kali, harus terus semakin dimaksimalkan lagi demi pertumbuhan Gereja GKE Maranatha Topan. Hal ini juga diatur dalam Tata Gereja GKE pasal 17.

Selain itu juga penulis juga menyoroti terkait kepercayaan jemaat terhadap praktik okultisme. Penulis sudah melakukan pelayanan secara pribadi dengan hamba Tuhan lainnya, yaitu pelayanan pelepasan artinya melepaskan diri dari keterikatan dari kepercayaan terhadap roh-roh dan benda-benda yang merupakan perbuatan dosa yang menduakan Allah. Menurut penulis, mereka harus menerima Tuhan Yesus dengan sungguh-sungguh dan dalam percakapannya konselor meyakinkan konseli bahwa kehidupan dari orang-orang percaya ada dalam kendali tangan Tuhan sehingga dalam kaitan ini mereka juga diingatkan agar tidak perlu mengantungkan hidup dan segala permasalahannya mereka kepada roh-roh dan bendabenda yang semua itu bukan perintah Tuhan.

Langkah berikutnya dalam mengatasi pelanggaran hukum Tuhan dalam jemaat penulis melakukan pendampingan pastoral secara khususnya dalam hal ini penulis tidak menghakimi apalagi menyudutkan yang bersangkutan, tidak boleh juga mengatakan bahwa saya mendapatkan informasi ini dari pihak tertentu sebab dalam pendampingan pastoral ada yang kode etik tertentu yang harus dipegang dan dihormati sebagai prinsip agar percakapan pastoral dalam berjalan sebagaimana yang diharapkan. Penulis sangat itu memposisikan diri sebagai sahabat yang datang untuk mendampingi konseli (anggota jemaat) yang menjadi pelaku yang melakukan pelanggaran hukum Allah. Dalam proses percakapan berlangsung konseli menceritakan secara jujur dan terbuka dan mereka akhirnya diberikan sebuah nasihat khusus kepada mereka untuk tidak mengulangi perbuatan itu sebab akan ada konsekuensi logis yang mereka akan terima baik itu sanksi sosial hukum adat, hukum negara dan hukum

40Wawancara Vic. Wahyu di Resort Nanga Tebidah, Kamis, 6 Mei 2019 pukul 07.00 WIB. 
Tuhan. Pada waktu mereka yang menyadari dan menyesali akan perbuatan yang mereka lakukan dan ingin sungguh-sungguh bertobat.

\section{6) Persekutuan Jemaat Rumah ${ }^{41}$}

Penulis dengan hamba Tuhan setempat melihat bahwa konsep persekutuan rumah jemaat ini sangat menolong jemaat GKE Maranatha Topan, menurut dari kesan dengan diadakan persekutuan jemaat rumah mereka merasa dirangkul oleh Gereja dan hamba Tuhan dengan hadirnya konsep persekutuan ini. Berbeda dengan kebaktian rumah tangga pada umumnya, dalam kebaktian ini mereka diberikan waktu untuk menceritakan segala macam masalah yang selama ini tersimpan dalam hati dengan jujur dan terbuka alasan mereka memilih menjauhkan diri dari ibadah umum dan kebaktian rumah tangga. Dalam kebaktian itu juga disertai dengan perenungan firman Tuhan yang disesuaikan dengan pergumulan yang mereka alami sehingga mereka semakin dikuatkan, diteguhkan sehingga mereka mempunyai pengharapan akan adanya sebuah pemulihan atau rekonsiliasi dengan pihak-pihak yang pernah berseteru. Dan terakhir mereka mendapatkan pendampingan pastoral secara intensif oleh Pendeta Resort dan Hamba Tuhan setempat dan oleh karena pertolongan Roh Kudus, beberapa di antara mereka dapat melepaskan pengampunan dan mau memaafkan kepada orang-orang yang ada di gereja. Mereka yang tadinya berseteru kini menjalin hubungan yang baik dengan pihak yang bersangkutan. Meskipun belum sepenuhnya yang hadir dalam persekutuan jemaat rumah dapat melepaskan pengampunan dan memaafkan, namun bukan berarti pelayanan ini gagal semua harus terus menerus diupayakan dengan penuh kesabaran dan penyerahan diri total kepada Allah sang pemilik kehidupan dan biarlah Roh Allah yang berkeja dalam setiap pribadi lepas pribadi.

Persekutuan jemaat rumah mempunyai dampak bagi sekolah minggu yang sebelum orangtuanya tidak mendukung anaknya untuk mengikuti kebaktian sekolah minggu. Dengan adanya persekutuan jemaat rumah, orangtuanya mendukung anak ikut kebaktian sekolah minggu dan orangtuanya pun ikut kebaktian umum dan juga ikut mendukung segala pelayanan yang dilakukan oleh hamba Tuhan dan para majelis.

\section{7) Kebaktian Rumah Tangga}

Pertumbuhan iman jemaat GKE Maranatha Topan juga sangat ditentukan dari kerinduan jemaat untuk mengikuti kebaktian rumah tangga dan dengan sebuah harapan kedepannya mereka dapat ikut mengambil bagian dalam pelayanan bagi pertumbuhan Gereja

41 Persekutuan jemaat rumah yang dimaksud ini berbeda dengan kebaktian rumah tangga pada umumnya sebagaimana yang diketahui oleh banyak orang. Persekutuan jemaatrumah ini merupakan hasil dari studi yang di lakukan oleh Sinode GKE ke salah satu Sinode Gereja yang ada di Korea yang juga merupakan mitra GKE dalam rangka kerjasama ekumenis lintas Gereja. Persekutuan jemaatrumah, adalah sebuah persekutuan yang di dalamnya hanya dihadiri oleh semuaanggota keluargatersebut yang selama ini memilih untuk menjauhkan diri dari ibadah umum di GKE Marnatha Topan maupun kebaktian rumah tangga oleh karena beragam faktor atau alasan di dalamanya. Hal ini merupakan sebuah konsep ibadah yang baru diterapkan beberapa tahun belakangan ini oleh Sindoe GKE. 
GKE Maranatha Topan. Selain itu semasa penulis menjadi Ketua Resort di GKE Nanga Tebidah, penulis pernah melakukan sebuah kebijakan bagi seluruh gereja-gereja yang tergabung dalam Resort Nanga Tebidah untuk membentuk dan menerapkan suatu sistem rayon atau wilayah yang berdasarkan wilayah atau lingkungan. Secara khusus di GKE Maranatha Topan yang jumlahnya sekitar kurang lebih 98 KK (Kepala Keluarga). Jumlah 98 KK ini akan dibaginya menjadi 3 rayon atau sektor atau wilayah yang berdasarkan lokasi. Sejak diterapkannya uang khas Gereja bertambah dan tingkat kehadiran jemaat GKE Maranatha Topan meningkat sehingga membuat Gereja menjadi penuh. Pada akhirnya, berdampak bagi komisi remaja dan pemuda GKE mereka dapat setiap minggunya ikut dalam kebaktian remaja pemuda karena gereja akhirnya bisa memberikan kesejahteraan bagi hamba Tuhan yang melayani disana. Inilah yang meningkatkan antusias remaja dan pemuda dalam mengikuti kebaktian remaja dan pemuda beserta dengan segala kegiatannya.

\section{Kesimpulan}

Pertumbuhan Gereja GKE Maranatha Topan ialah tanggungjawab kolektif dari warga jemaat itu sendiri bukan hanya dipahami sebagai sepenuhnya tanggung jawab seorang hamba Tuhan dan majelis setempat. Sebab baik hamba Tuhan maupun majelis merupakan bagian dari jemaat hanya saja yang membedakan mereka diberikan kepercayaan oleh Tuhan melalui jemaatnya untuk mengemban tugas untuk melakukan penatalayan di dalam gereja. Jika ingin bertumbuh berarti harus ada harga yang harus dibayar yakni perubahan dari dalam setiap pribadi warga jemaat baik dari spritualitas, mentalitas, kesadaran diri untuk menyadari pentingnya sebuah rekonsiliasi sebagai warga gereja yang mengalami konflik melalui proses pengembalaan pribadi (konseling pastoral) ataupun ibadah rumah jemaat, kesadaran untuk memberikan perpuluhan kepada gereja, kesadaran untuk mendukung di antara jemaat, sesama majelis, kesadaran untuk belajar berorganisasi dan juga mendukung hamba Tuhan yang sedang dipercayakan Tuhan dalam mengembalakan jemaat-Nya. Setelah ada perubahan secara personal sebagai warga GKE Marantha Topan barulah kemudian mengadakan sebuah reformasi yaitu bukan kaum awam yang menjadi ketua majelis melainkan harus hamba Tuhan yang sudah dipersiapakan dan diperlengkapi di bangku pendidikan teologi.

\section{Referensi}

Chao, Nathanael. "Bahan Ceramah Pertumbuhan Gereja di STT Iman Jakarta". Jakarta, 2000. Davies, Erick J. Dingwall \& John Langdon. Alam Gaib. Surabaya: Pustaka Progresif, 1964.

Dokumen. Dokumen kesekretariatan. Desa Topan Nanga, 2017.

Gavran, Mc. Back to Basic to Basic in Church Growth. Wheaton: Tyndale, 1981.

Griffifth, Michael. Gereja dan Panggilannya Dewasa ini. Jakarta: BPK Gunung Mulia, 1991.

Lie, Paulus. Mereformasi Gereja. Yogyakarta: ANDI, 2010.

Nazir. Metode Penelitian. Jakarta: Ghalia Indonesia, 2011.

Schwarz, Christian A. "pertumbuhan-gereja-yang-alamiah". gsjarks. 
Sugiyono. Cara Mudah Menyusun: Skripsi, Tesis dan Disertasi,. Bandung: Alfabeta, 2013.

Wagner, C. Peter. Gereja Saudara Dapat Bertumbuh. Malang: Gandum Mas: Penerbit Gandum Mas, 1997.

Wagner, C. Peter. Memimpin Gereja Anda Agar Bertumbuh (Harvest Publication House). Jakarta: Harvest Publication House, 1995.

Werren, Rick. Pertumbuhan Gereja Masa Kini: Gereja yang Mempunyai Visi-Tujuan. Malang: Gandum Mas, 2000.

\section{Sumber Wawancara}

Pnt. Marbudin, Wawancara dilakukan oleh Osias Kause di Topan, 15 November 2018.

Dengo Purwanto, sebagai Ketua Majelis GKE Maranatha Topan, Wawancara oleh Osias Kause, pada 8 September 2018.

Rusmina, sebagai Guru Sekolah Minggu, Wawancara oleh Osias Kause, pada 11 September \& 6 November 2018.

Mikha Sebagai Ketua SPPR, Wawancara oleh Osias Kause, pada 8 September, 11 Oktober 2018.

Darius Eder, Wawancara dilakukan oleh Osias Kause,di Topan, pada 7 September 2018.

Vic.Wahyu, Wawancara di lakukan oleh Osias Kause, di Nanga Tebidah, pada 6 Mei \& 15 Oktober 2018.

Ev.Yosep Kay, Wawancara di lakukan oleh Osias Kause,di Topan, pada 21 Oktober 2018.

Darius Eder, Wawancara di lakukan oleh Osias Kause, di Topan, pada 7 November 2018.

Wawancara Diakon Darius, S.Pdk Guru Agama di SD Topan Kamis 6 Mei 2019 pukul 09.00 WIB.

\section{Internet}

Vera Yunani, Kesenjangan Pendidikan Desa https://www.kompasiana.com/verayunani/590178dbf07a61cc76284ae3/kesenjanganpendidikan-desa-dan-kota?page=all, diakses: 20 November 2019.

Belo, Yosia. "PENDIDIKAN AGAMA KRISTEN DALAM MATIUS 28: 19-20." Jurnal LUXNOS 1.2 (2020): 127-133. 